Asian Journal of Medical and Biological Research ISSN 2411-4472 (Print) 2412-5571 (Online) https://www.ebupress.com/journal/ajmbr/

\title{
Article \\ Comparative efficacy of LaSota, B1 and Mukteswar Strain vaccines for Newcastle Disease Virus (NDV) in layer chickens
}

\author{
Md. Tazul Islam Sarker ${ }^{1}$, Md. Mostafizer Rahman ${ }^{1}$, Md. Fakhruzzaman ${ }^{1 *}$ and Md. Nurnoby Islam ${ }^{2}$ \\ ${ }^{1}$ Department of Microbiology, Hajee Mohammad Danesh Science and Technology University, Dinajpur-5200, \\ Bangladesh \\ ${ }^{2}$ Department of Medicine, Surgery and Obstetrics, Hajee Mohammad Danesh Science and Technology \\ University, Dinajpur-5200, Bangladesh
}

*Corresponding author: Dr. Md. Fakhruzzaman, Associate Professor, Department of Microbiology, Faculty of Veterinary and Animal Science, Hajee Mohammad Danesh Science and Technology University, Dinajpur-5200, Bangladesh. Phone: +8801727777486; Fax: +88-0531-61311; E-mail: fakhrul.hstu@gmail.com

Received: 07 November 2021/Accepted: 23 December 2021/ Published: 30 December 2021

Copyright (C) $2021 \mathrm{Md}$. Tazul Islam Sarker et al. This is an open access article distributed under the Creative Commons Attribution 4.0 International License (https://creativecommons.org/licenses/by/4.0/), which permits unrestricted use, distribution, and reproduction in any medium, provided the original work is properly cited.

\begin{abstract}
The control of Newcastle Disease (ND) relies on the use of safe and effective vaccines. Live vaccines which are prepared with lentogenic strains of Newcastle Disease Virus (NDV) are now more frequently used in broilers and layers than vaccines prepared from chemically inactivated strains of NDV mixed with adjuvant. This is because live freeze-dried vaccines can be produced on a large scale at a relative low cost. The vaccines are easy to administer on large scale, and rapidly stimulate cell-mediated and mucosal surface immunity. The present study was designed to compare the efficacy of LaSota, B1 and Mukteswar Strain vaccines for NDV in layer chickens. Findings of our present study indicated that production of HI-antibody titre was higher in birds of group A (512) vaccinated with ND LaSota, compared to those of group B (256) vaccinated with RDV (Mukteswar strain); group C (128) vaccinated with ND B1 (B1 strain) Hitchner at six weeks after vaccination. Thus, the ND LaSota vaccine was found to be superior to some extent than ND B1 Hitchner. However, as regards vaccination of chicks against NDV in earlier days, the use of lentogenic strains are recommended although it should be kept in mind that vaccination with LaSota strains would cause greater problems in young susceptible birds than Hitchner B1 strain and even though LaSota induces stronger immune response.
\end{abstract}

Keywords: Newcastle Disease Virus; LaSota; B1; Mukteswar strain vaccine

\section{Introduction}

Newcastle disease (ND) is an acute contagious disease of pet, free living and domestic birds. The causative agent Newcastle disease virus (NDV) is a negative-sense, single-stranded RNA virus which belongs to the genus Avulavirus and falls in the family Paramyxoviridae (Alexander, 1997). The virus is distributed worldwide either as naturally circulating virus or as a vaccine virus. It has been constant in at least 241 species of birds representing 27 of 50 orders of the class Aves (Alexander, 1995b). ND is widely adaptable in type and severity of the disease it produces. It is complicated because various isolates and strains of the virus may induce variations in the severity of the disease even in a given host, such as, the chickens (Alexander, 1991). A variety of NDV isolates and strains have been listed around the world (Ballagi-Pordany et al., 1996). As regards epidemic (epizootic) incidences, NDV causes disease in intensive poultry and is responsible for high economic losses up to $100 \%$ mortality (Alexander, 1991; Awan et al., 1994). Moreover, ND is recognized as an enzootic 
disease in most countries of Africa, Asia and some countries of Europe (Awan et al., 1994; Ballagi-pordany et al., 1995; 1996). In case of Bangladesh, ND has been delineated as endemic with prevalence of Viscerotropic velogenic strains (Chowdhury et al., 1982; Islam et al., 2003). ND may appear pear as Pneumotropic (Respiratory), Neurotropic (Nervous), Viscerotropic (visceral organs) and Velogenic viscerotropic (digestive system and other visceral organs). Among the strains that are of comparatively less virulence (Lentogenic) are $\mathrm{B}_{1}, \mathrm{~F}$ and LaSota which have been widely used as vaccine. The least pathogenic (Lentogenic) strains $\mathrm{B}_{1}$ (Hitchner et al., 1948), LaSota (Winterfield et al., 1957), and F (Asplin, 1952) are used in birds of all ages by intra-nasal or intra-ocular routes, admixture with drinking water, or spraying. The asymptomatic enteric form of infection is caused by lentogenic strains (Lancaster, 1981) that produced no clinical signs or pathology and is detected only by virus isolation from the gut or feces and by presence of specific antibodies (French et al., 1964; Simmons, 1967; Mc Ferran et al., 1988). Complete histories of the B, and LaSota strains supplied accounts of their interesting discoveries (Hitchner, 1975; Goldhalf, 1980). Hitchner's form (Hitchner and Johnson, 1948) is a mild or inapparent respiratory infection of chickens caused by lentogenic strains. Mortality by this strain is rare in birds of any age. The control of ND depends on the use of safe and effective vaccines. Live vaccines prepared with lentogenic strains of NDV are now more widely used in broilers than vaccines prepared from chemically inactivated strains of NDV, mixed with adjuvant (Biggs et al., 1988; Alexander, 1991). This is due to live freeze-dried vaccines can be produced on a large scale at a relatively low cost. The vaccines are easy to administer on a large scale, and rapidly stimulate humoral, cell-mediated and mucosal surface immunity. Infections with NDV (either naturally or NDV vaccines) may induce cell-mediated immunity, humoral immunity, local immunity and passive immunity (Alexander, 1991; 1997). Humoral immunity can be detected and measured by several serological tests (Tizzard, 1982; Alexander, 1991). Serological testing for antibody to NDV has primarily utilized either the hemagglutination inhibition (HI) test or virus neutralization test (VNT). The HI has been used as the standard test. Recently, enzyme-linked-immunosorbent assay (ELISA) has replaced the HI test (Adair et al., 1989; Brown et al., 1990; Alexander, 1991). In Bangladesh, different live vaccines containing lentogenic strains of NDV are imported, but efficacy of these vaccines in relation to climatic condition, distribution and transportation are not studied properly and thoroughly. Sometimes, the farmers are suspicious of prophylactic nature of the agent. A number of relevant questions are faced by the scientists and field veterinarians as to the immunogenicity, retention of virus titer, stability and such other qualities of vaccine. Therefore, the present work has been undertaken to determine the antibody titer in chicken following vaccination with Medivac ND La Sota ${ }^{\circledR}$ (La Sota strain), RDV $^{\circledR}$ (Mukteswar strain), and Izovac B1 Hitchner ${ }^{\circledR}$ $\left(\mathrm{B}_{1}\right.$ strain) and to evaluate the comparative antibody production of the vaccines used in this study.

\section{Materials and Methods}

\subsection{Study area}

The study was carried out in the experimental animal sheds of experimental farms in Rangpur district of Bangladesh under the supervision of Department of Microbiology, Hajee Mohammad Danesh Science and Technology University (HSTU), Dinajpur-5200, Bangladesh.

\subsection{Experimental chickens}

A total number of 3000 day-old-chicks of ISA Brown breed with the history of vaccination of parent stock against Newcastle disease (ND) were collected from the Phenix Poultry Ltd., Dhaka and carried to the experimental farm located in Baharkachna, Rangpur, under the supervision of Department of Microbiology, HSTU, Dinajpur. The birds were fed with Quality poultry feed and water and litter maintaining strict biosecurity and other pre-requisites required for rearing such birds.

\subsection{Study design}

There was total 3000 experimental layer chicken. These birds were divided into three experimental groups (group-A, group-B and group-C). Group-A, group-B and group-C was vaccinated with ND Lasota, RDV and ND B1 respectively. In all groups, first vaccination was performed at day $5,2^{\text {nd }}$ and $3^{\text {rd }}$ doses were given at day 21 , and 56 respectively. First blood collection of all groups of chickens were performed at 10 weeks for HI titre whereas $2^{\text {nd }}, 3^{\text {rd }}, 4^{\text {th }}, 5^{\text {th }}$ and $6^{\text {th }}$ collections were done at $12,14,16,18$ and 20 weeks of age respectively.

\subsection{Propagation of virus in chicken embryo inoculation}

Lyophilized virus suspension used as antigen in HA/HI test was thawed and treated with antibiotic (Gentamicin $1.0 \mathrm{mg} / \mathrm{ml}$ ) of which $0.1 \mathrm{ml}$ was inoculated into each of five 10-day-old embryonated chicken eggs through air sac (AS) route. The eggs were then incubated at $37^{\circ} \mathrm{C}$ and observed twice daily for five days. The embryos that 
died within 24 hours of inoculation were discarded and those remained alive for 4 days were chilled at $4^{\circ}-8^{\circ} \mathrm{C}$ for 1-2 hours (Cottral, 1978).

\subsection{Harvesting and storage of allantoic fluid as antigen}

Eggs were chilled at $4^{\circ} \mathrm{C}$ for two hours to kill the embryo and to reduce the contamination of allantoic fluid (AF) with blood and other extraneous material during harvesting. Each egg was swabbed with cotton soaked with $70 \%$ alcohol to disinfect and remove any dust from the shells. The sterilized forceps and scissors were dipped into absolute alcohol and flamed immediately before use. The eggshell above the air space was removed and $\mathrm{AF}$ was collected aseptically.

\subsection{Collection and processing of blood for $\mathrm{HI}$ test}

Collection of blood was done from the right jugular vein with the sterile syringe and needle and placed in slanting position for $1 \mathrm{hr}$. at room temperature. Then the clot was detached from the wall of the syringe carefully, allowed it to settle down and afterward serum was collected. Collected serum was centrifuged at 1500 at rpm for 15 minute to obtain clear serum and then stored at $-20^{\circ} \mathrm{C}$ temperature until use.

\subsection{Collection and preparation of 0.5 and $2 \%$ chicken red blood cell (cRBC) suspension}

Chicken blood was collected either from the jugular vein or from wing vein with sterile syringe and needle containing anticoagulant (Alsever's solution) at the rate of $5 \mathrm{ml}$ for $5 \mathrm{ml}$ blood. Following collection, blood sample was washed with PBS and centrifuged at the rate of $500 \mathrm{rpm}$ for 5 minutes. The supernatant was discarded and cRBC was collected and then $2 \%$ and $0.5 \%$ cRBC suspensions were prepared in PBS for slide and micro-HA tests and $\mathrm{HI}$ test respectively. The unused cRBC suspension was stored at $4{ }^{\circ} \mathrm{C}$ until used (Khan, 1992).

\subsection{Haemagglutination Inhibition (HI) test procedure}

The procedure of HI test was followed as per method described by Anon. (1971) and divided into two parts:

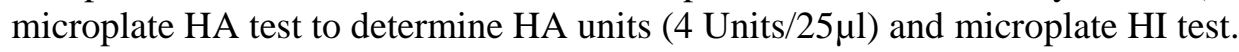

\section{Results}

The present study was conducted to compare the efficacy of following vaccination with ND-LaSota ${ }^{\circledR}$ (Lasota strain), RDV (Mukteswar strain), and Izovac B1 Hitchner ${ }^{\circledR}$ (B1 strain). After vaccination, sample was collected randomly from 16 birds from 1-unit of 1000 birds. HI titres of serum of birds of Group A vaccinated with ND-LaSota $^{\circledR}$ vaccine are shown in Table 1. Birds of this group were vaccinated with ND-LaSota at 5 days of age and then booster doses were given at 21 and 56 days respectively. First blood collection for HI titer was performed at 10 weeks then at 12,14,16,18 and 20 weeks of age. HI titres of serum of birds of Group B vaccinated with RDV are shown in Table 2. Birds of this group were vaccinated with RDV (Mukteswar) at 5 days of age and then at day 21 and 56 respectively. HI titres of serum of birds of Group C vaccinated with ND B1 (B1 strain) vaccine are shown in Table 3. Birds of this group were vaccinated with ND B1 (B1 strain) at five days of age and then at 21 and 56 days of age.

Comparative HI titres of serum of birds vaccinated with different vaccines are shown in Table 4.

Table 1. HI antibody titres of serum of chickens vaccinated with ND-LaSota ${ }^{\circledR}$ vaccine (Group A).

\begin{tabular}{|l|l|l|l|l|}
\hline Sl. No. & Age at wks. & DPV & Titer range & Average titer \pm SD \\
\hline 1 & 10 & 2 wks. & $64-256$ & $128 \pm 38.74$ \\
\hline 2 & 12 & 4 wks. & $128-256$ & $256 \pm 22.61$ \\
\hline 3 & 14 & 6 wks. & $256-1024$ & $512 \pm 55.34$ \\
\hline 4 & 16 & 8 wks. & $256-512$ & $256 \pm 42.44$ \\
\hline 5 & 18 & 10 wks. & $128-512$ & $256 \pm 35.58$ \\
\hline 6 & 20 & 12 wks. & $128-256$ & $128 \pm 30.21$ \\
\hline P value & & & & $0.0002 * *$ \\
\hline
\end{tabular}

Legends: ** Means significant at $(\mathrm{p}<0.01)$ 1\% level; P means Probability, DPV=Days post vaccination, $\mathrm{SD}=\mathrm{Standard}$ deviation 
Table 2. HI antibody titres of chickens vaccinated with RDV (Group B).

\begin{tabular}{|l|l|l|l|l|}
\hline Sl. No. & Age at wks. & DPV & Titer range & Average titer \pm SD \\
\hline 1 & 10 & 2 wks. & $64-128$ & $64 \pm 16.64$ \\
\hline 2 & 12 & 4 wks. & $128-256$ & $128 \pm 22.18$ \\
\hline 3 & 14 & 6 wks. & $128-256$ & $256 \pm 22.78$ \\
\hline 4 & 16 & 8 wks. & $128-256$ & $128 \pm 28.47$ \\
\hline 5 & 18 & 10 wks. & $64-128$ & $64 \pm 25.47$ \\
\hline 6 & 20 & 12 wks. & $32-64$ & $64 \pm 8.42$ \\
\hline P value & & & & $0.0251^{* *}$ \\
\hline
\end{tabular}

** Means significant at $(\mathrm{p}<0.01) 1 \%$ level; P means Probability

Table 3. HI antibody titres of chickens vaccinated with ND B1 (B1 strain) vaccine (Group C).

\begin{tabular}{|l|l|l|l|l|}
\hline Sl. No. & Age at wks. & DPV & Titer range & Average titer \pm SD \\
\hline 1 & 10 & 2 wks. & $64-128$ & $128 \pm 12.44$ \\
\hline 2 & 12 & 4 wks. & $128-256$ & $256 \pm 17.87$ \\
\hline 3 & 14 & 6 wks. & $128-256$ & $128 \pm 12.67$ \\
\hline 4 & 8 wks. & $64-128$ & $128 \pm 20.52$ \\
\hline 5 & 16 & 10 wks. & $64-128$ & $64 \pm 15.42$ \\
\hline 6 & 20 & 12 wks. & $32-128$ & $64 \pm 18.28$ \\
\hline$P$ value & & & & $0.0028^{* *}$ \\
\hline
\end{tabular}

** Means significant at $(\mathrm{p}<0.01) 1 \%$ level; P means Probability

Table 4. Comparative HI titres of serum of chickens vaccinated with different ND vaccines.

\begin{tabular}{|l|l|l|l|l|l|l|l|}
\hline \multirow{2}{*}{$\begin{array}{l}\text { Sl. } \\
\text { No. }\end{array}$} & Name of unit & \multicolumn{6}{|c|}{ Weeks post vaccination (WPV) } \\
\cline { 3 - 8 } & & $\mathbf{2}$ wks. & 4 wks. & 6 wks. & 8 wks. & 10 wks. & 12 wks. \\
\hline 1 & Group A & 128 & 256 & 512 & 256 & 256 & 128 \\
\hline 2 & Group B & 64 & 128 & 256 & 128 & 64 & 64 \\
\hline 3 & Group C & 128 & 256 & 128 & 128 & 64 & 64 \\
\hline
\end{tabular}

\section{Discussion}

It may be noted that the range of $\mathrm{HI}$ titres of the three vaccinated groups of birds are more or less of similar order when measured on 10,12,14, 16, 18 and 20 weeks age of birds. However, the Mean \pm SD of sera on these occasions clearly indicate a higher value of ND-LaSota (LaSota strain) than RDV (Mukteswar strain), and Izovac $B_{1}$ Hitchner $\left(B_{1}\right.$ strain). In this context, the utility of measurement of $\mathrm{HI}$ antibodies of sera to detect the protection capacity of birds from an infection with NDV needs to be mentioned. Lancaster (1966) observed that serological response of chickens to NDV either from natural infection or vaccination is revealed by the appearance of both $\mathrm{HI}$ and $\mathrm{VN}$ (virus neutralization) antibodies. It was also stated that $\mathrm{HI}$ and $\mathrm{VN}$ antibodies though follow a similar course, but VN antibody persist longer and in relatively higher titres (Hossain, 1950; Hossain et al., 1972; Haplin, 1978). It should further be mentioned that HI test provides a measurement of the ability of serum from an exposed bird to inhibit agglutination of chicken RBC by NDV, whereas VN or SN indicates the ability of serum to neutralize this infective property of NDV and therefore, provides more precise information about the immune response (Hanson, 1964). Sera samples of birds possessing HAI titre of 80 or above revealed a level of VNI of 102.48 or above when the birds demonstrated protection against challenge infection with virulent NDV. On the other hand, sera samples possessing HAI titre of 40 or less revealed VNI of 101.3 or less when the birds could not resist challenge infection with NDV. As regards to the principal objectives of the present study, it may be stated that production of HI-antibody was higher in birds of group A vaccinated with ND LaSota ${ }^{\circledR}$ compared to those of group B vaccinated with RDV (Mukteswar) and group C vaccinated with Izovac B1 Hitchner ${ }^{\circledR}$. Thus, the ND-LaSota was found to be superior to some extent than Medivac, RDV ${ }^{\circledR}$, Izovac B1 Hitchner ${ }^{\circledR}$. However, as regards vaccination of chicks against NDV in earlier days the use of lentogenic strains is recommended although it should be kept in mind that vaccination with LaSota strains would create considerately greater problems in young susceptible birds than Hitchner $\mathrm{B}_{1}$ strain and even though LaSota produces a stronger immune response (OIE Manual, $4^{\text {th }}$ Edition, 2000). In spite of vigorous vaccination schedules, ND is still a havoc to the poultry industry and a number of outbreaks have been recorded 
even in vaccinated chicken flocks (Siddique et al., 1986). Other factors like poor vaccine quality is a common problem in developing countries and can be the result of poor manufacturing standards, lack of adequate storage facilities, application of expired vaccine batches, faulty application and vaccine handling during transportation (Vui et al., 2002). Heat stress and water deprivation also lead to production of steroids and thus resultantly immunosuppression (Sil et al., 2002). The control of ND relies on the use of safe and effective vaccines. Live vaccines prepared with lentogenic strains of NDV are now more commonly used in broilers than vaccines prepared from chemically inactivated strains of NDV, mixed with adjuvant. This is because live freeze-dried vaccines can be produced on a large scale at a relatively low cost. The vaccines are easy to administer on a large scale, and rapidly stimulate humoral, cell mediated and mucosal surface immunity. In view of the above discussion, it is essential that the following aspect of vaccination with RDV, B1 strain and LaSota strain may be performed in future.

a) A comparative study on the schedule of vaccination with RDV, $B_{1}$ strain and LaSota.

b) Assessment of genetic reversion of $F, B$, and LaSota strain after using vaccine.

c) Determination of efficacy of RDV, $\mathrm{B}_{1}$, LaSota and such other strains for mass vaccination on food-based method and

d) Influence of maternal antibody in chicks on the efficacy of Mukteswar, $B_{1}$ and LaSota strains of vaccine.

\section{Conclusions}

In this study, comparative efficacy of different Newcastle disease virus vaccines namely ND-Lasota ${ }^{\circledR}$ (Lasota strain), RDV ${ }^{\circledR}$ (Mukteswar strain) and Izovac B1 Hitchner ${ }^{\circledR}$ (B1 strain) vaccines regarding the production of HIantibody was accomplished in chickens. The results obtained in this study indicate that the HI antibody titres of chickens of group-A vaccinated with ND-LaSota fluctuated between 64-1024. In Group-B administered with $\mathrm{RDV}^{\circledR}$, the HI titres varied between 64-256. When considered the HI antibody titres of group C inoculated with B1 Hitchner®, HI titre shown 64-256. Thus, it was found that birds of group A, B and C vaccinated with NDLasota ${ }^{\circledR}$, RDV and commercial Izovac $B_{1}$ Hitchner $^{\circledR}$, Group A induced higher level of antibody titers than that of other two groups (Group B and C). From our current study, it may be concluded that among three commercial vaccines used in this work, vaccine containing Lasota strain, was found to elucidate slightly higher HI antibody response compared to those containing B1 and RDV (Mukteswar strain) of NDV respectively.

\section{Acknowledgements}

The authors express their sincere gratitude to the Department of Microbiology, Faculty of Veterinary and Animal Science, Hajee Mohammad Danesh Science and Technology University, Dinajpur-5200, Bangladesh, for supporting and providing all the laboratory facilities to conduct the research works.

\section{Conflict of interest}

None to declare.

\section{Authors' contribution}

Md. Tazul Islam Sarker, Md. Mostafizer Rahman and Md. Fakhruzzaman designed the study. Md. Tazul Islam Sarker did the actual research work. Md. Fakhruzzaman and Md. Nurnoby Islam drafted the original manuscript, critically reviewed and edited the manuscript. All authors have read and approved the final manuscript.

\section{References}

Adair BM, TMS McNulty, TJ Connor and K Burns, 1989. Quantitative estimation of Newcastle Diseases virus antibody level in chickens and turkeys by ELISA. Avian Pathol., 18: 175-192.

Alexander DJ, 1997. Newcastle Disease and other avian Paramyxoviridae infections, in Diseases of Poultry $10^{\text {th }}$ edition, edited by: B.W. Calnek, H.J. Barnes, C.W. Beard, L.R. McDougall \& Y.M. Saif. Ames, Iowa, USA: Iowa state University press, 541-569.

Alexander DJ, 1995a. Guest editorial: Newcastle disease in countries of the European Union. Avian Pathol., 24: 3-10.

Alexander DJ, 1995b. Review. The epidemiology and control of avian influenza and Newcastle disease. J. Comp Pathol., 112: 105-126.

Alexander DJ, 1991. Newcastle disease and other paramyxovirus infections, in diseases of poultry 9 edition, edited by: B.W. Calnek, H.J. Barnes, C.W. Beard, W.M. Reid and H.W. Jorder Jr. Ames, Iowa, USA: Iowa State University Press, pp. 496-519. 
Amin MM, AJ Sarkar, MR Ali and M Saifuddin, 1987. Investigation of some parameters for Measuring Immune Response Following Vaccination Against Newcastle Disease. Bang. Vet. J., 21: 33-42.

Anon, 1971. Methods for examining poultry biologics and for identification and quantifying avian pathogens. Newcastle disease, U.S. National Academy of sciences, Washington D.C.

Asplin FD, 1952. Immunization against Newcastle disease with a virus of low virulence (strain F) and observations on subclinical infection in partially resistant fowls. Vet. Rec., 64: 245-249.

Awan MA, MJ Otte and AD James, 1994. The epidemiology of Newcastle disease in rural poultry: a review. Avian Pathol., 23: 405-423.

Ballagi-Pordany A, E Wehmann, J Herczeg, S Belak and B Lomniczi, 1996. Identification and grouping of Newcastle disease virus strains by restriction site analyses of a region from the F gene. Arch.Virol., 141: 243261.

Ballagi-Pordany A, A Lagerkvist, E Wehmann, J Herczeg, J Baranyi, U Landergren, S Belak and B Lomniezi, 1995. Identification and grouping of Newcastle disease virus strains by restriction site analyses and sequencing of a region from the $\mathrm{F}$ gene in Application of polimerase chain reaction (PCR) in veterinary virology edited by Ballagi-Pordany, Uppsala. Sweden. University of Agricultural Science Uppsala.

Biggs PM, PG Box, F Brown, I Mcconnel, JB Mcferren and EJL Soulsby, 1998. Vaccination in the control of infectious diseases in farm animal-BVA trust project: Future of animal health control edited by Smith, H \& Payne, J.M. UK: 21-27.

Brown J, RS Resurrection and TG Dickson, 1990. The relationship between the hemagglutination-inhibition test and the enzyme-linked immunosorbent assay for the detection of antibody to Newcastle disease. Avian Dis., 34: 585-587.

Cheesbrough M, 1985. Medical laboratory manual for tropical countries. Vol. H. Micro. pp. 443-445.

Chowdhury TIMFR, AJ Barker, MM Amin and WIMA Hossain, 1982. Studies on Newcastle disease in Bangladesh. A Research Report, Sec 2. The role of residual maternal antibody on immune response and selection of an optimum age for primary vaccination of chicks. pp. $12-20$.

Cottral GE, 1978. Manual of standardized methods for veterinary microbiology. Cornell University press. Ithaca, NY, pp. 47-52.

French EL, 1964. Evidence of freedom of Australian flocks from infection with Newcastle disease virus. Australian Vet. J., 40-119.

Goldhaft TM, 1980. Guest editorial: Historical note on the origin of the LaSota strain of Newcastle disease virus. Avian Dis., 24: 297-301.

Hanson RP, 1964. Newcastle Disease: An evolving pathogen. Univ. Wisconsin Press, Madison.

Haplin B, 1978. Pauems of Animal Disease.Immunity and Epidemiology. The English Language Book Society and Bailliere Tindal, London, pp. 151-157.

Hitchner SB, 1975. Guest editorial: Serendipity in science: Discovery of the B-1 Strain of Newcastle disease virus. Avian Dis., 19: 215-223.

Hitchner SB and EP Johnson, 1948. A virus of low virulence for immunizing fowls against Newcastle disease (Avian Pneumoencephalitis). Vet. Med., 43: 525-530.

Hossain MM, JH Browfr and EW Tilton, 1972. Sensitivity to an acute gamma radiation exposure of successively irradiated generations of the cowpea weevil. J. of Eco. Entom., 65: 1566-1568.

Hossain K, 1950. A Case of Pernicious Anaemias; Treated by combination of folic acid and liver extract. Antiseptic., 47: 291-293.

Islam MR, QMF Huque, MJ Giasuddin, and MM Rahman, 2003. Assessment of maternally derived antibody of commercial flock against Newcastle disease. Proceedings of $3^{\text {rd }}$ international poultry show and seminar, Bangladesh china friendship conference center, Dhaka, Bangladesh $28^{\text {th }}$ February- $2^{\text {nd }}$ March 2003.

Khan MSR, 1992. Cell mediated immune response, antigenicity and rapid diagnosis of Duck plague virus. M.S. Thesis submitted to the department of Microbiology and Hygiene, Faculty of Vet. Science, BAU, Mymensingh.

Lancaster JE, 1981. Newcastle disease. In Gibba EPJ (ED), virus disease of Food Animals, Vol II, Disease Monographs, Academic press, New York, pp.433-465.

McFerran JB and RM Mccracken, 1988. Newcastle disease in: Alexander D.J. (ED) Newcastle disease kluwer Academic Publishers. Boston, pp.161- 183.

OIE Manual, 2000. Manual of standards for Diagnostics tests and Vaccines. $4^{\text {th }}$ ed, pp. 189-207.

Siddique M, MA Sabri and MZ Khan, 1986. Outbreaks of Newcastle disease in vaccinated flocks in and around Faisalabad. Pakistan Vet. J., 6: 41-45. 
Sil GC, PM Das, MR Islam and MM Rahman, 2002. Management and disease problems of cockrels in some farms of Mymensingh, Bangladesh. Int. J. Poult. Sci., 1: 102-105.

Simmons JG, 1967. Poole-Frenkel effect and Schottky effect in metal-insulator-metal systems. Phys. Rev., 155: 657.

Tizzard I, 1982. Immunity in foetus and newborn animals P. 155. An Introduction to Veterinary Immunology.

Vui TQ, JE Lohr, MN Kyule, KH Zessin and MPO Baumann, 2002. Antibody levels against Newcastle disease virus, Infectious bursal disease virus and Influenza virus in rural chicks in Vietnam. Int. J. Poult. Sci., 1: 127132.

Winterfield RW, CL Goldman and EH Seadale, 1957.Newcastle Disease Immunization Studies: 4. Vaccination of Chickens with B1, F and Lasota Strains of Newcastle Disease Virus Administered through the Drinking Water. Poul. Sci., 36: 1076-1088. 